\title{
SUCCESS AND FAILURE FACTORS OF THE IMPLEMENTATION OF COMPUTER BASED INFORMATION SYSTEMS IN THE GOVERNMENT INSTITUTIONS OF MATARAM CITY: INFORMATION SYSTEM RESOURCE PERSPECTIVE
}

\author{
Budi Santoso $^{1}$, Emilia Septiani ${ }^{2}$ \\ ${ }^{1}$ The Faculty of Economics and Business, Univertsity of Mataram, hebato@gmail.com \\ ${ }^{2}$ The Faculty of Economics and Business, University of Mataram, emiliaseptiani@unram.ac.id
}

\begin{abstract}
The purposes of this study were to identify the factors of success and failure of the implementation of computer-based information systems at the Departments of Government in the city of Mataram, and to determine the position or to map the information system, information resources' perspectives. This research is a descriptive study by collecting primary data from 32 government agencies which was based on interviews based on the questionnaire that has been prepared. The results showed that the persistence of the mismatch of education and skills resource officers from the perspective of human information. Inadequate readiness of the hardware owned by the Government Agencies. Most of operating systems (OS) used and Microsoft Windows-based applications are still vulnerable to a computer virus attacks. SOP is not owned by most of the Government Agencies, and the some have still not complied. The computer networking is still underdeveloped in most of the Government Agencies. Finally, the data or information has not been fully utilized by almost all levels of management to the decision-making process. To that end, it is suggested that it is necessary to strengthen and empowering capabilities and expertise personnel, upgrading and server procurement, the development of wireless-based network for the short term, while maintaining a commitment at all levels of management to utilize the data/ information in the decision-making process. From theoretical point of view, this implementation of information systems was not good a lesson learned which has to be followed by any organization.
\end{abstract}

Keywords: information resources, human resources, hardware, software, networking and procedures.

\section{INTRODUCTIOAN}

It has been recognized that globalization has an impact in all areas of life. Globalization is characterized by an information superhighway era that is characterized by the speed of information flow (McLeod, 2004). The speed and ease of information access leads managers and executives to give serious attention to information because negligence in information management affects business competition for profit-oriented organizations, and on providing unsatisfactory services to non-profit organizations or the public sector.

There are two main factors that encourage all parties to pay more attention to information that is the organization's resources, that is, the complexity of the business to be faced, and the improved computer capabilities (McLeod, 2004). If one of these factors does not exist, then the pressure on the need for information management is not important. Therefore, information that is the output of an information system must be managed properly.

Besides being an output, information is also a key element in an information resource. The other elements of information resources are human (brain ware), hardware (hardware), software (software), procedures, and network (networking). The integration of organizing the elements of information resources in such a way, that process the data (raw materials), and processed in the processor (hardware and software) will produce the 
outcome of meaningful information for managers or executives in decision making (Napitupulu \& Sensuse, 2014; McLeod, 2004).

The need for a computer-based information system encourages organizations to master the system so that control can be done optimally. For that, there are several ways that can be taken by the organization to be able to have a computer-based information system, the outsourcing and / or insourcing in whole or in part. Whatever the choice, the organization is faced with the fact that the implementation of computer-based information systems can succeed or fail.

Several previous studies have shown that factors of success and failure of the implementation of computer-based information systems have been generally identified and not grouped into systematic information resources, ie top management support, stakeholder engagement, good development methodology, strong leadership, international support and so on (Abdelsalam, Reddick, \& Elkadi, 2012; Akcam, Guclu, Guler, Hekim, \& Ogune, 2012; Al-Azri, Al-Salti \& Al-Karaghouli, 2010; Buchwald, 1997; Elpez \& Fink, 2006; Napitupulu \& Sensuse, 2014). In the previous study, it was also identified that the praxis in developing countries is the absence of top management commitment in the utilization of computer-based information systems in decision-making and system management, and most of these phenomena occur in organizations in the public sector (Al- Azri et al., 2010; Cauter, Snoeck, \& Crompvoets, 2013; Napitupulu \& Sensuse, 2014; Shin, Song, \& Kang, 2008; Sirma, Obegi, \& Ngacho, 2014).

As the capital of West Nusa Tenggara province, Mataram City has officially become a pilot city of widespread Wi-Fi utilization in several areas. To support this program, the regional work unit or SKPD under Mataram City administration has developed a computer-based information system. Based on the latest published report that of 32 units SKPD under the administration of Mataram City as much as 25 SKPD has been developed and has a computer-based information system (Abduh, 2015). From the initial monitoring obtained information that only a few information systems that are in SKPD that operate well and used routinely.

Previous research has identified the success and failure factors of computer-based information system implementation in both private and public sector organizations, but these factors have not been grouped regularly and systematically. Grouping factors of success and failure of the implementation of computer-based information systems from the perspective of information resources, human, hardware, software, procedures, networks and data are urgent to examine and review.

From the description, there are several things that the target of the study are (1) how are the factors of success and failure of the implementation of computer-based information systems of government agencies in the City of Mataram viewed from the side of information resources?; and (2) where is the position of computer-based information system of government agencies in Mataram City from the perspective of information resources based on success factors and system failure?

\section{LITERATURE REVIEW}

This section discussed some theoretical and previous research findings that were relevant with success and failure factors in implementation of computer-based information systems in organizations.

\section{System Approach}

Several ways can be chosen by an organization to be able to have or utilize a computer-based information system, namely: first, by outsourcing as a whole, meaning 
the entire information resources provided by the service provider or vendor information system. The main disadvantage of this approach is the security of data and information resulting from the organization having no control both physically and conceptually (McLeod, 2004). The second way, that is, organizations outsource in part by means of physical information resources owned by the organization while conceptual resources, such as software can be developed by external parties. The third approach, that is, organizations organize and develop software with internal resources or full insourcing. Each of these systems approaches has a disadvantage, and according to the results of the study the minimum weakness and long-term benefits will be obtained if the system approach is done by fully insourcing if sufficient funds (Buchwald, 1997; Cauter et al., 2013; McLeod, 2004).

\section{Success and Failure of Information System}

There are several criteria that can be implemented to justify a computer-based information system is successful or failure. The majority of information specialists agree that the shorter the life cycle of a system's development, the less successful or failing the system is. Conversely, the longer or longer the system development life cycle, the more successful the system developed (Buchwald, 1997, Poon \& Wagner, 2001; McLeod, 2004; Vaughan, 2003). The development of an information system encompasses several stages that are quite long and complex, so that the failure of the implementation of computer-based information system has a serious impact on the organization both short and long-term financial consequences (Sirma et al., 2014; Ziemba \& Oblak, 2013).

The condition or state of the elements of information resources has been identified in several studies have been done previously either implicitly or explicitly is a factor of success and failure of the implementation of computer-based information systems. Here, discussed the results of the research identify the success factors and failure of the implementation of computer-based information systems based on information resources elements.

Human, as brain ware is one of the important elements in information resources, and without human existence no matter how sophisticated a hardware and other elements, the system is meaningless and useless. In research conducted in some government organizations in several developing countries (Shin et al., 2008) found that the level of education and training contributed to the success and failure of the implementation of computer-based systems. Another study conducted by (Nawi et al., 2012) also identifies that the suitability and age of persons responsible for the implementation of information systems play a role in the success and failure of information system implementation. Recent research conducted by (Napitupulu \& Sensuse, 2014) also resulted that commitment and seriousness of top management became one of the decisive factors in the success and failure of information system implementation. However, the previous studies have not mentioned specifically employment status of those who involved the information systems.

Elements of information resources are not less important is the hardware that is the physical resources of an information system. The reliability and capability of the hardware is a factor of success and failure of the implementation of computer-based information systems that are supported in research conducted on government organizations in several developing countries by (Buchwald, 1997; Cauter et al., 2013; Nawi et al., 2012; et al., 2008; Vaughan, 2003). Other supporting factors such as electricity availability, and space conditions are also factor of success and failure of computer-based information system implementation. In addition, backup or availability 
of server backups is also part of the success factor and failure of the implementation of the information system (Nawi et al., 2012; Vaughan, 2003; Ziemba \& Oblak, 2013). It is however, the previous researches have neglected one important supporting factor might contribute to the success or failure of implementation of information systems, namely electricity.

As a conceptual information resource, software is also a critical success factor and failure of information system implementation. This opinion was led by (Abdelsalam et al., 2012; Al-Azri et al., 2010; Poon \& Wagner, 2001) who conducted research in some non-profit organizations in several countries. Suitability, ease of use and reliability (robustness) are also factors of success and failure of information system implementation encountered in research conducted by (Nars et al., 2012; al., 2012; Poon \& Wagner, 2001; Shin et al., 2008; Vaughan, 2003). It is also that one thing which was most the previous studied overlooked was the executive support for the procurement of software, whether the organization have installed the applications legal or illegal.

The isolation of information systems that essentially work procedurally or in a certain order, procedures in the form of written documents and standards are also found to be factors of success and failure of the implementation of computer-based information systems found in the results of research conducted by (Abdelsalam et al., 2012; Al-Azri et al., 2010; Alhomod \& Shafi, 2013; Almajed \& Mayhew, 2013; Cauter et al., 2013). Compliance of information system users and the ease of documented procedures is also a critical determinant of the success and failure of the implementation of computer-based information systems that are examined in studies conducted in several government organizations in several countries being developed by (Cauter et al., 2013; Napitupulu \& Sensuse, 2014 ; Shin et al., 2008). The compliancy of standard operating procedures has been overlooked by some previous studies. This study has included the compliancy aspects to be observed.

The existence of both wire and wireless network infrastructure contributes to the determinants of success and failure of information system implementation, and this situation is encountered in research conducted by (Napitupulu \& Sensuse, 2014; Nawi et al., 2012; Shin et al., 2008; Vaughan, 2003). Other studies conducted by some researchers (Poon \& Wagner, 2001; Shin et al., 2008; Sirma et al., 2014; Vaughan, 2003) identify that network reliability and speed are also factors that determine the success and failure of information systems implementation. As resulted from studies conducted in western countries on which the infrastructures for computer networks have been established, the most previous studied have overlooked the reliability of computer networking in organization.

Research conducted by several scholars found that the form and format of the fields to be used in the data entry process contributed to the success factors and failures of the implementation of information systems (Abdelsalam et al., 2012; Akcam et al., 2012; AlAzri et al., 2010; Buchwald, 1997; Cauter et al., 2013). It was also found that periodic updating of data and information was also a factor of success and failure of the implementation of computer-based information systems (Hastie, 2006; Nawi et al., 2012; Shin et al., 2008; Sirma et al., 2014). Facilities that are able to perform searches according to user needs and demands are also critical factors for the success and failure of computerbased information system implementation as detected in research conducted by some researchers (JAL, 2008; Kaur \& Aggrawal, 2013; Vaughan, 2003). Recent research shows that top management commitment is a factor of success and failure of information system implementation (Napitupulu \& Sensuse, 2014). The utilization of data/ information was neglected by most previous studied because from western scholars' point 
of views, executives might aware of the importance of data/ information for their decision-making processes.

Based on the previous study of the results identified several success factors and failure of the implementation of computer-based information systems, namely the elements of information resources. Thus, it can be illustrated the interrelationship of the elements of information resources with the indicators and items used as the basis of the research framework.

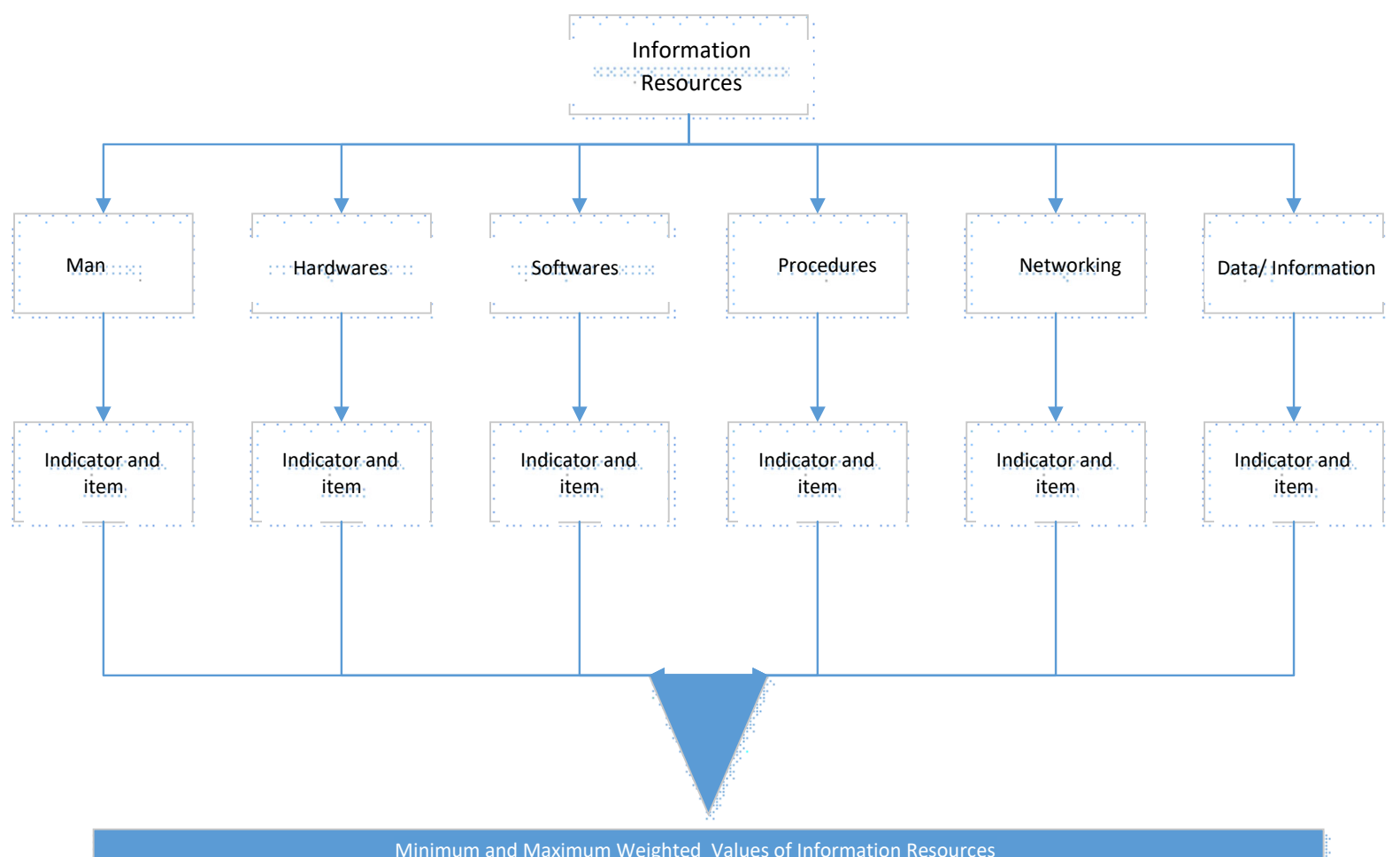

Figure 1. Research Framework

\section{METHOD}

This research is a descriptive research that sought to describe and explain in depth about the phenomenon of success and failure factors of the implementation of computerbased information system (the Government Departments and Agencies/ Boards) in the region of Mataram City. In this study, the data were collected by census method for three months period (July to September 2017). The number of SKPD / institutions within the administration of Mataram City is 32 (thirty-two). Key informant for each institution was interviewed as many as 1 (one) official or staff in the Electronic Data Center (EDC) and/ or data processing (information) section. To collect data and information, this research utilized several instruments, which were questionnaires as interview guides, voice recorder and camera (video recorder).

Table 1. Variable, Item, Indicator and Measuring Scale of Information Resources

\begin{tabular}{|c|l|l|l|l|l|}
\hline No. & \multicolumn{1}{|l|}{$\begin{array}{c}\text { Variables/ } \\
\text { Elements }\end{array}$} & Indicator & Item & Scale & \multicolumn{1}{c|}{ Score } \\
\hline 1. & $\begin{array}{l}\text { Man/ brain } \\
\text { ware }\end{array}$ & Education & Last education & Nominal & $\begin{array}{l}\text { 1. Senior High School } \\
\text { 2. Diploma } \\
\text { 3. Bachelor }\end{array}$ \\
\hline
\end{tabular}




\begin{tabular}{|c|c|c|c|c|c|}
\hline No. & $\begin{array}{l}\text { Variables/ } \\
\text { Elements }\end{array}$ & Indicator & Item & Scale & Score \\
\hline & & & & & $\begin{array}{l}\text { 4. S2 } \\
\text { 5. S3 }\end{array}$ \\
\hline & & Suitability & $\begin{array}{l}\text { suitability of } \\
\text { educational } \\
\text { background }\end{array}$ & Nominal & $\begin{array}{l}\text { 1. Not Suitable } \\
\text { 2. Less Suitable } \\
\text { 3. Suitable }\end{array}$ \\
\hline & & Skill level & Skill level & Nominal & $\begin{array}{l}\text { 1. Basic } \\
\text { 2. Middle } \\
\text { 3. Advanced }\end{array}$ \\
\hline & & $\begin{array}{l}\text { Employment } \\
\text { Status }\end{array}$ & $\begin{array}{l}\text { Employment } \\
\text { Status }\end{array}$ & Nominal & $\begin{array}{l}\text { 1. Honorary } \\
\text { 2. Civil Servant }\end{array}$ \\
\hline & & Age & Age & Nominal & $\begin{array}{l}\text { 1. }<=20 \text { years old } \\
2.21-25 \text { years old } \\
3.26-30 \text { years old } \\
\text { 4. } 31-35 \text { years old } \\
5.36-40 \text { years old } \\
6.41-45 \text { years old } \\
7 .>=46 \text { years old }\end{array}$ \\
\hline \multirow[t]{7}{*}{2.} & \multirow[t]{7}{*}{ Hardware } & Server & $\begin{array}{l}\text { Server } \\
\text { capability in } \\
\text { routine } \\
\text { operations }\end{array}$ & Nominal & $\begin{array}{l}\text { 1. Inadequate } \\
\text { 2. Less adequate } \\
\text { 3. Adequate }\end{array}$ \\
\hline & & Server backup & $\begin{array}{l}\text { The existence } \\
\text { of server } \\
\text { backup }\end{array}$ & Nominal & $\begin{array}{l}\text { 1. Not existence } \\
\text { 2. Existence }\end{array}$ \\
\hline & & $\begin{array}{l}\text { Server backup } \\
\text { conditions }\end{array}$ & $\begin{array}{l}\text { Conditions and } \\
\text { capability of } \\
\text { server backup }\end{array}$ & Nominal & $\begin{array}{l}\text { 1. Not worth it } \\
\text { 2. Worth it }\end{array}$ \\
\hline & & Electricity & Power installed & Nominal & $\begin{array}{l}\text { 1. Inadequate } \\
\text { 2. Less adequate } \\
\text { 3. Adequate }\end{array}$ \\
\hline & & & UPS & Nominal & $\begin{array}{l}\text { 1. No } \\
\text { 2. Yes, but inadequate } \\
\text { 3. Yes and adequate }\end{array}$ \\
\hline & & Rooms & $\begin{array}{l}\text { Adequacy of } \\
\text { room }\end{array}$ & Nominal & $\begin{array}{l}\text { 1. Inadequate } \\
\text { 2. Less adequate } \\
\text { 3. Adequate }\end{array}$ \\
\hline & & & $\begin{array}{l}\text { Room } \\
\text { temperature }\end{array}$ & Nominal & $\begin{array}{l}\text { 1. Not cool } \\
\text { 2. Less cool } \\
\text { 3. Cool }\end{array}$ \\
\hline \multirow[t]{5}{*}{3.} & \multirow[t]{5}{*}{ Software } & $\begin{array}{l}\text { Operating } \\
\text { System (OS) }\end{array}$ & OS in server & Nominal & $\begin{array}{l}\text { 1. Windows } \\
\text { 2. Linux } \\
\text { 3. Solaris }\end{array}$ \\
\hline & & & $\begin{array}{l}\text { OS in terminal } \\
\text { or client level }\end{array}$ & Nominal & $\begin{array}{l}\text { 1. Apple Macintosh } \\
\text { 2. Windows } \\
\text { 3. Linux }\end{array}$ \\
\hline & & $\begin{array}{l}\text { End user } \\
\text { computing } \\
\text { software }\end{array}$ & $\begin{array}{l}\text { Conformity } \\
\text { with regular } \\
\text { routine }\end{array}$ & Nominal & $\begin{array}{l}\text { 1. Inappropriate } \\
\text { 2. Less appropriate } \\
\text { 3. Appropriate }\end{array}$ \\
\hline & & & $\begin{array}{l}\text { Level of easy } \\
\text { to use }\end{array}$ & & $\begin{array}{l}\text { 1. Easy } \\
\text { 2. Less easy } \\
\text { 3. Quite easy }\end{array}$ \\
\hline & & Robustness & Stability & Nominal & $\begin{array}{l}\text { 1. Not stable } \\
\text { 2. Rarely } \\
\text { 3. Never }\end{array}$ \\
\hline
\end{tabular}

84 Success and Failure Factors of The Implementation of Computer ... 


\begin{tabular}{|c|c|c|c|c|c|}
\hline No. & $\begin{array}{l}\text { Variables/ } \\
\text { Elements }\end{array}$ & Indicator & Item & Scale & Score \\
\hline & & $\begin{array}{l}\text { Executive } \\
\text { support }\end{array}$ & $\begin{array}{l}\text { Development } \\
\text { and } \\
\text { procurement }\end{array}$ & Nominal & $\begin{array}{l}\text { 1. No } \\
\text { 2. Yes }\end{array}$ \\
\hline \multirow[t]{3}{*}{4.} & \multirow[t]{3}{*}{ Procedure } & $\begin{array}{l}\text { Standard } \\
\text { operating } \\
\text { procedures }\end{array}$ & $\begin{array}{l}\text { SOP are } \\
\text { documented }\end{array}$ & Nominal & $\begin{array}{l}\text { 1. Not documented } \\
\text { 2. Documented, but not } \\
\text { completed } \\
\text { 3. Documented and } \\
\text { completed }\end{array}$ \\
\hline & & Compliances & $\begin{array}{l}\text { Compliance } \\
\text { with SOP }\end{array}$ & Nominal & $\begin{array}{l}\text { 1. Not compliance } \\
\text { 2. Sometimes } \\
\text { 3. Always compliance }\end{array}$ \\
\hline & & Ease & $\begin{array}{l}\text { SOP is easy to } \\
\text { understand }\end{array}$ & Nominal & $\begin{array}{l}\text { 1. Not easy } \\
\text { 2. Quite easy } \\
\text { 3. Very easy }\end{array}$ \\
\hline \multirow[t]{2}{*}{5.} & Networking & Infrastructure & $\begin{array}{l}\text { Type of } \\
\text { infrastructure }\end{array}$ & Nominal & $\begin{array}{l}\text { 1. No network } \\
\text { 2. Wireline } \\
\text { 3. Wireless }\end{array}$ \\
\hline & & Reliability & $\begin{array}{l}\text { Speed and } \\
\text { stability of } \\
\text { network }\end{array}$ & Nominal & $\begin{array}{l}\text { 1. Not reliable } \\
\text { 2. Less reliable } \\
\text { 3. Reliable }\end{array}$ \\
\hline \multirow[t]{5}{*}{6.} & $\begin{array}{l}\text { Data/ } \\
\text { Information }\end{array}$ & Form field & $\begin{array}{l}\text { Availability of } \\
\text { forms for data } \\
\text { input }\end{array}$ & Nominal & $\begin{array}{l}\text { 1. Not available } \\
\text { 2. Available }\end{array}$ \\
\hline & & $\begin{array}{l}\text { Form field } \\
\text { format }\end{array}$ & $\begin{array}{l}\text { Accordance } \\
\text { with rules of } \\
\text { database } \\
\text { structure }\end{array}$ & Nominal & $\begin{array}{l}\text { 1. Unstructured } \\
\text { 2. Structured }\end{array}$ \\
\hline & & Updating & $\begin{array}{l}\text { Periodical data } \\
\text { update }\end{array}$ & Nominal & $\begin{array}{l}\text { 1. Never } \\
\text { 2. Rarely } \\
\text { 3. Routine }\end{array}$ \\
\hline & & SQL & $\begin{array}{l}\text { Availability of } \\
\text { conditional } \\
\text { data search } \\
\text { facility }\end{array}$ & Nominal & $\begin{array}{l}\text { 1. Not available } \\
\text { 2. Available }\end{array}$ \\
\hline & & Utilization & $\begin{array}{l}\text { Utilization of } \\
\text { data or } \\
\text { information in } \\
\text { decision } \\
\text { making process } \\
\end{array}$ & Nominal & $\begin{array}{l}\text { 1. Never } \\
\text { 2. Rarely } \\
\text { 3. Always }\end{array}$ \\
\hline
\end{tabular}

After data was processed and processed according to scientific studies, tabulation and distribution frequency graphs were exposed to describe each variable or element of information resources. The determination of the weighing value for each of the variables or elements of the information resources used as the basis of consideration of the decision of success or failure, namely:

a. Brain ware (human) is given a weight of 15 percent

b. Hardware (hardware) is rated 15 percent

c. Software (software) is also given a 15 percent

d. Procedures (procedures) are also weighted 15 percent

e. Networking (network) is given a weight of 15 percent

f. Data or information is rated 25 percent

Data or information is given the greatest weight compared to others does not mean that this element is more important than others, but in this study based on previous literature review it is said that data / information is a conceptual resource. Practical 
conceptual resources are difficult to assess with money, for that reason, the contribution that becomes important in the decision of success and failure of the implementation of a computer-based information system when these variables or elements are of low value:

a. Calculating the minimum value and the weighted value of the total value of all variables, that is by multiplying the lowest value of the score with the weight (minimum weighted value), and multiplying the highest score of the score by weight (weighted maximum value);

b. Multiplying a score with a weighted or weighted value for each variable;

c. Summing the weighted scores of each variable;

d. Matching the amount value (at Point 4) on the line reflecting the minimum and maximum weighted values; and

e. Deciding if the value of the number (based on Point 5) close to the maximum value, means that the implementation of information systems tend to lead to success, but the reverse, when closer to the minimum value, means there is a tendency of information system implementation will lead to failure.

\section{RESULTS}

After identifying factors that contribute to the success and failure of the implementation of computer-based information systems, this section analyzes and elaborates the partial position and aggregate information systems from an information resource perspective. The following table and graphs presented scores or scores of each element or perspective of information resources from information systems owned by the Office and the Agency in the Mataram City Governmental Environment.

Table 2. Scores and Benchmarks of the Departments and the Agencies Based on the Perspective of Information Resources

\begin{tabular}{|c|c|c|c|c|c|c|c|c|c|c|c|c|}
\hline \multirow[b]{2}{*}{ No. } & \multirow[b]{2}{*}{$\begin{array}{l}\text { Information } \\
\text { Resource }\end{array}$} & \multicolumn{2}{|c|}{ 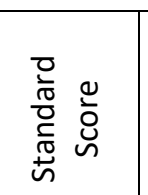 } & \multirow{2}{*}{$\begin{array}{l}\frac{0}{ \pm} \\
\frac{1}{0.0} \\
\frac{000}{10} \\
3\end{array}$} & \multicolumn{2}{|c|}{ 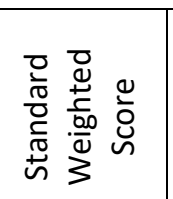 } & \multirow{2}{*}{ 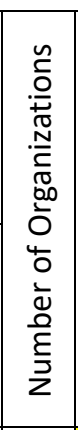 } & \multirow{2}{*}{ 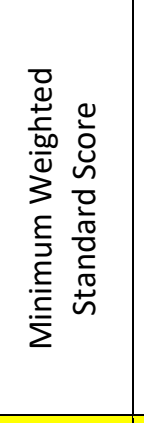 } & \multirow{2}{*}{ 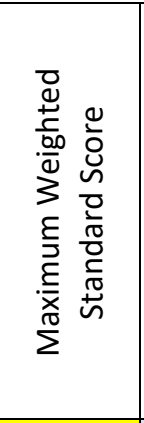 } & \multirow{2}{*}{ 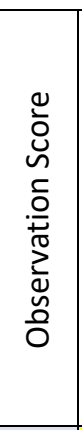 } & \multirow{2}{*}{ 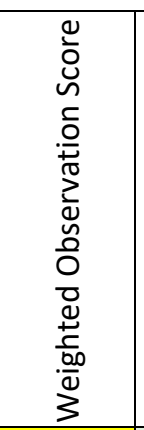 } & \multirow{2}{*}{ 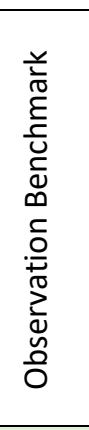 } \\
\hline & & : $\frac{\xi}{\mathcal{E}}$ & 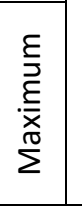 & & $\frac{\xi}{\underline{\xi}}$ & 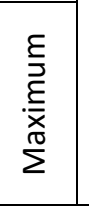 & & & & & & \\
\hline 1. & Man & 5 & 20 & 15 & 75 & 300 & 32 & 2,400 & 9,600 & 423 & 6,345 & $66 \%$ \\
\hline 2. & Hardware & 7 & 20 & 15 & 105 & 300 & 32 & 3,360 & 9,600 & 417 & 6,255 & $65 \%$ \\
\hline 3. & Software & 6 & 17 & 15 & 90 & 255 & 32 & 2,880 & 8,160 & 361 & 5,415 & $66 \%$ \\
\hline 4. & Procedures & 3 & 9 & 15 & 45 & 135 & 32 & 1,440 & 4,320 & 204 & 3,060 & $71 \%$ \\
\hline 5. & Networking & 2 & 7 & 15 & 30 & 105 & 32 & 960 & 3,360 & 98 & 1,470 & $44 \%$ \\
\hline 6. & Data/Information & 5 & 12 & 25 & 125 & 300 & 32 & 4,000 & 9,600 & 204 & 5,100 & $53 \%$ \\
\hline & & & & & & Aggr & gate & 15,040 & 44,640 & & 27,645 & $62 \%$ \\
\hline
\end{tabular}




\section{2,000}

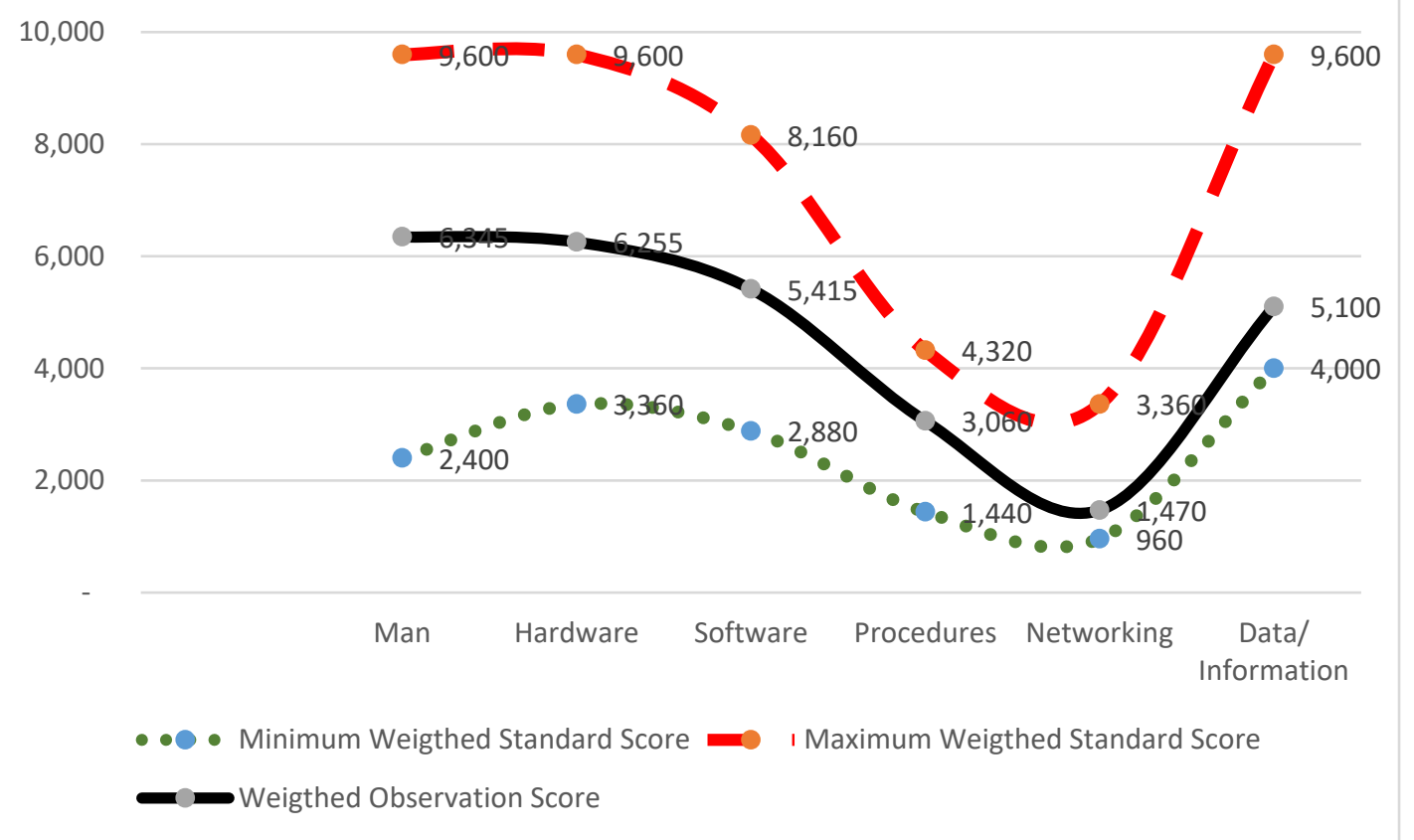

Figure 2. Standard Weighted Score and Observations Weighted Score from Departments and Agencies Based on Perspective of Information Resources

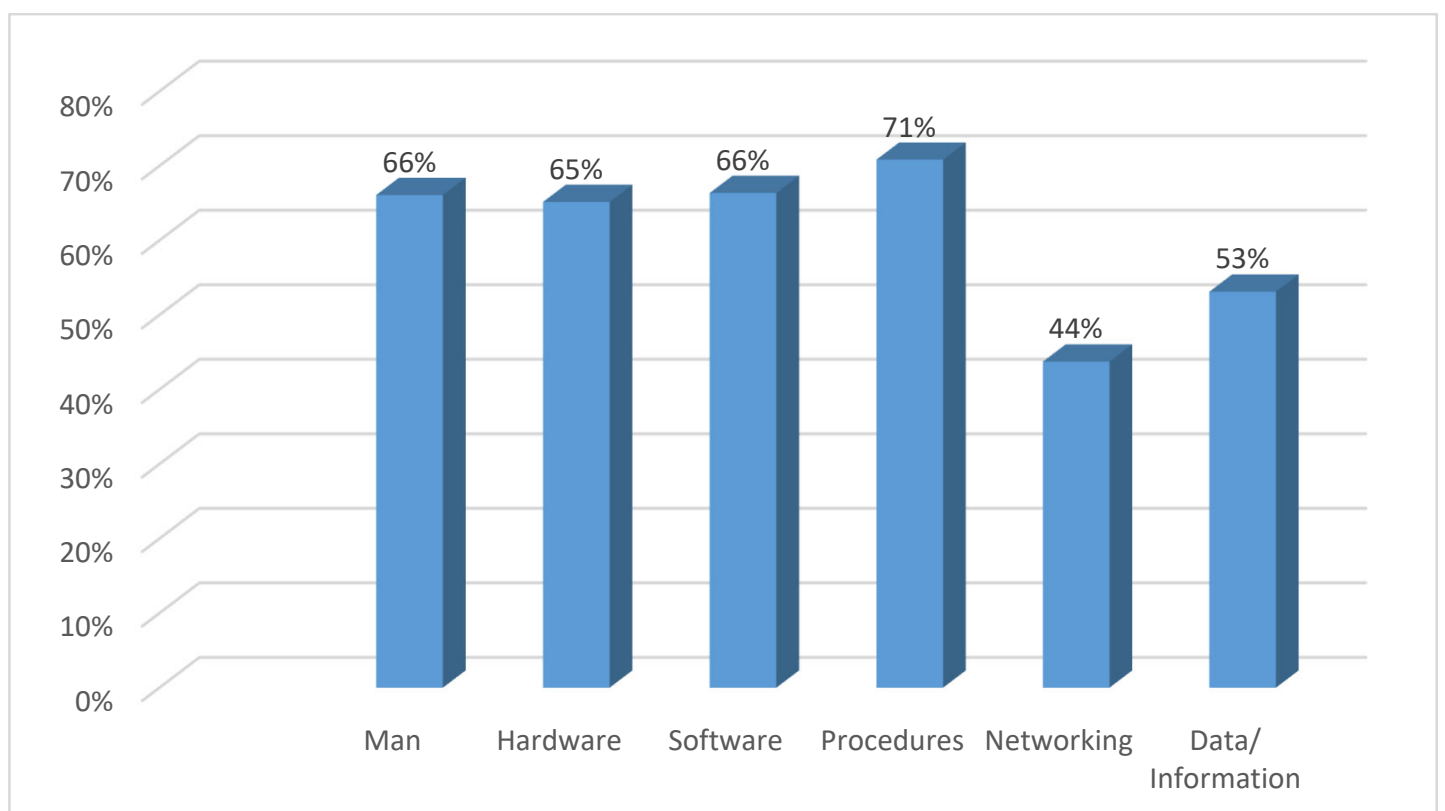

Figure 3. Benchmark Overall Observation of Departments and Agencies in the Mataram City Governmental Environment Based on Information Resource Perspective

Based on the data presented in Table 2, Figure 2 and Figure 3 can be explained that overall each information resource element has benchmarks above 50 percent, except for network information resources that have benchmarks of 44 percent. The network has a low benchmark because it has been described previously most of the Agency and Agency does not yet have a network. Data/ information resources have benchmarks near 50 percent because some of the items observed, such as the use of form fields, data updating, 
SQL and data/ information utilization have low scores. However, overall each benchmark is still not close to 100 percent.

As seen on Table 2 and Figure 2, the brain ware had 66 percent of observation score that was resulted from the contribution of those who involved in the systems had education backgrounds were not information systems related educations and experiences. Besides that, most of them were not permanent employees in the organization. They have been hired for a certain period of time to help permanent employees to entry data. Once the entry data project completion, they were cheesed. These aspects were overlooked by most of previous studies because the work environment in which they studied, were different to organizations studied in this research.

From hardware point of view, the 65 percent benchmarking score from the observation was most contributed by nearly 90 percent of the organizations being observed did not have networking infrastructure. Most the computers in the organization have operated individually or without connected by wire or wireless networking. This condition might influence the uses of illegal software that was copied from untrusted sources. Indeed, the electricity black-out might be contributed to the whole aspects of the running information systems owned by the organization. Poorly, the systems were not appropriately back upped by the uninterrupted power supply (UPS) due to insufficient funds to purchase suitable UPS to fulfil the needs of implemented information systems.

As mentioned above, due to unified use of personal computer (PC) in the organization, the software has been installed in each individual PC with various versions and specifications. As a result, the benchmarking score was only 66 percent, and this might lead to serious issue, once the copy rights have been revealed in the future.

The procedure aspect has been 71 percent that was the highest benchmarking score achieved. This was contributed by most the information systems implemented have been supported by the standard operating procedure (SOP). It is, however, the real practices in the organization were not fully compliant with the SOP that has to be followed.

Unfortunately, the lowest benchmarking score was networking aspect (44 percent). As indicated before, most of the organizations that implemented the information systems were not infrastructurally by appropriate networking. This might result in disintegrated and inefficient information system operation to support decision making process in the organization. This was also that the opportunities were revealed the uses of illegal software in the individual PC.

Due to unappropriated implementation of information systems, data that have been inputted, might not result in valid information which can be used by the end users in their jobs. This condition was also led to the reluctance for executive in the organization to use information in his/ her decision-making process. This poor information might be also resulted from the uses of individual PC in the organization.

It can be explained that from the results of the partial analysis described above, the aggregate benchmark of information resources from computer-based information systems owned by the Agency and the Agency within the Mataram City Government, amounting to 62 percent. Maximum standard weighted score is 44.640 points (100 percent), while weighted observation scores of 27,645 points, so it can be said that the aggregate position of information resources from the information system of the City Government of Mataram leads to the point maximum. This explanation becomes clearer with the exposure in the following figure. 


\begin{tabular}{|c|c|c|c|}
\hline \begin{tabular}{|l|} 
Minimum \\
Weigthed Standard \\
Score (15.040)
\end{tabular} & $\begin{array}{c}\text { Weighted } \\
\text { Observation } \\
\text { Seigthed } \\
\text { Score (27.645) }\end{array}$ \\
\hline
\end{tabular}

Figure 4. Information Resource Position Mapped in One Line of Weighted Score Minimum and Maximum Standards

Ideally, the information resource position of a computer-based information system to operate effectively and efficiently is the same as the maximum score or with a benchmark of 100 percent. However, the ideal condition is relatively difficult to achieve, therefore, with a benchmark of 62 percent, the Office and the Agency in the Mataram City must try to improve all elements in its information resources to be able to score benchmarks close to or achieve maximum score.

As such, from theoretical point of view, the implementation of information systems in the organizations was not compliant in any aspects due to the benchmarking score for individual and aggregate aspects did not meet 100 percent, but even not closed to 90 percent. There have not been any tolerances for any score that did not achieve 100 percent. Finally, this can be said that the implementation of information systems in the organization was a bad practice that has been the lesson learned which has to be avoided in the future implementation of information systems in any organization.

\section{CONCLUSION AND SUGGESTION}

Identified in the research that the factors of success and failure of the implementation of computer-based information systems in the Office and the Agency in the Mataram City Government are as follows.

\section{Conclusion}

Based on the research that has been done and the results of data or information analysis can be summed up some things as follows.

a. Human resources information with benchmark of 66 percent caused by most of officials or staff with a final high school equivalent or equivalent, the existence of mismatches of educational background with job description of information and communication technology, and there are still many officials or staff who are honorary status. These conditions contribute to the success and failure of the implementation of computer-based information systems.

b. Benchmark hardware resources with benchmarks of 65 percent reflected by most Department and Agency have not or do not have servers, insufficient server and computer space, inadequate UPS is still the case, and inconvenient room temperature.

c. Software information resources with benchmark of 66 percent perceived as still often occur hangs or application damage is dominated by Microsoft Windows-based applications that are vulnerable to computer viruses, and the lack of support from superiors for the development of simple applications for the routine operational support of the organization.

d. The standard operating procedure that has benchmark of 71 percent which is the highest score in this research, this condition is caused by the many departments and agencies that do not have SOP in its operation, even if already have SOP, but less compliance, and SOPs that have been there are still difficult to understood. 
e. The information resources of the network with the lowest benchmark in this study, which amounted to 44 percent caused by most agencies and agencies do not have a network, and existing networks are also less reliable or often problematic.

f. Information resources that have benchmarks of 53 percent donated from most Department and Badan have not used the form field in data collection for input into the system, have not or do not update data periodically, the absence of SQL facilities, and data / information has not been utilized in the process decision making at both the management level and the executive level.

g. In aggregate, the position of computer-based information system owned by the Agency and the Agency in the Mataram City Governmental Environment from the perspective of information resources with benchmark of 62 percent. This means that in such a position, the overall readiness of the organization is still far from ideal conditions to serve the community maximally and prime.

\section{Suggestion}

To be able to improve the condition of computer-based information system owned by the Agency and the Agency in the Mataram City Government to be able to serve the community maximally and prime, there are some suggestions that can be considered, namely:

a. From the perspective of human resource information, need to do training or workshops related to ICT for high school educated or equal, and for those with no educational background or less in accordance with the field of ICT. For honorary workers should be upgraded to permanent employees to ensure their commitment is maintained.

b. In terms of hardware information resources, it is recommended that Department and Agency not have server to immediately install the server as needed for now and future, and make improvements to the room by paying attention to the area and temperature of the room.

c. From the point of view of software information resources, the use of Linux-based operating systems is preferable to Microsoft Windows-based, it is also recommended Linux-based applications to reduce virus attacks that can interfere with the routine operational smoothness of the organization, and do a clear communication with superiors to get support for simple application development for routine purposes.

d. In terms of procedural resources, the writing of SOPs is easily understood for Department and Agency that do not have SOP, and compliance with existing SOPs for those who already have SOP.

e. From the perspective of network resources, with the availability of Wi-Fi facilities in almost every personal computer (personal computer) and laptop computers (laptops), network development becomes cheaper, that is, by building a wireless network based for short-term purposes. For the long term, it is necessary to develop cable-based networks in each Department and Agency.

f. From the point of view of the data or information resources, it is necessary for the Department and the Agency to utilize the form to collect the data to be input into the system, periodic updating of data must be done so that the power available in the system is always UpToDate, preparing the external facilities for SQL in order to facilitate the fulfillment of the need data or information for the decision-making process, and there must be commitment at all levels of management to utilize data or information for both short-term and long-term decision-making processes. 


\section{REFERENCES}

Abdelsalam, H., Reddick, C. G., \& Elkadi, H. (2012). Success and Failure of Local eGovernment Projects: Lessons Learned from Egypt. Cairo, Egypt: Cairo University.

Abduh, A. (2015). Laporan Keterangan Pertanggungjawaban Akhir Masa Jabatan Walikota Mataram Periode 2010-2015. Mataram: Kota Mataram.

Akcam, B. K., Guclu, A. N., Guler, A., Hekim, H., \& Ogune, G. (2012). Critical Success Factors of IT Enabled Organization Change in Hierarchical Government Organizations: LIAS Case. International Journal of Economics and Management Science, 2(1), 25-35.

Al-Azri, A., Al-Salti, Z., \& Al-Karaghouli, W. (2010). The Successful Implementation of E-Government Transformation: A Case Study in Oman. European, Mediterranean \& Middle Eastern Conference on Information Systems.

Alhomod, S., \& Shafi, M. M. (2013). Success Factors of e-Learning Projects: A Technical Perspective. The Turkish Online Journal of Educational Technology, 12(2).

Almajed, A. I., \& Mayhew, P. (2013). An Investigation of the Critical Success Factors of IT Projects in Saudi Arabian Public Organizations. IBIMA Business Review, 2013(1), 10.

Buchwald, C. C. (1997). Canadian University Policy and the Information Infrastructure: Past Lessons, Future Directions. Canadian Journal of Communication, 22(2).

Cauter, L. V., Snoeck, M., \& Crompvoets, J. (2013). Public Administration Meets Information System Research: Analysing Failures of Intergovernmental Information Systems Via IS Success Models. Belgium: KU Leuven, Public Government Institute.

Elpez, I., \& Fink, D. (2006). Information Systems Success in the Public Sector: Stakeholders' Perspectives and Emerging Aligmnet Model. Issues in Informing Science and Information Technology, 3(1).

Hastie, S. (2006). What Makes Information Systems Projects Successful? Software Education. Wellington: Victoria University.

JAL, S. (2008). IT Project Benchmarking: Project Success Criteria Analysis. Canada: CATA.

Kaur, B. P., \& Aggrawal, H. (2013). Critical Failure Factors in Information System: An Exploratory Review. Journal of Global Research in Computer Science, 4(1).

Napitupulu, D., \& Sensuse, D. I. (2014). The Critical Success Factors Study for eGovernment Implementation. International Journal of Computer Applications, 89(16).

Nawi, H. S. A., Rahman, A. A., \& Ibrahim, O. (2012). Government ICT Procject Failure Factors: Project Stakeholders' Views. Journal of International Systems Research and Innovation. 
Poon, P., \& Wagner, C. (2001). Critical Success Factors Revisited: Success and Failure Cases of Information Systems for Senior Executives. Decision Support Systems, $30,393-418$.

Raymond McLeod, J. (2004). Sistem Informasi Manajemen (8 ed.). Jakarta: PT. Indeks.

Shin, S., Song, H., \& Kang, M. (2008). Implementing e-Government in Developing Countries: Its Unique and Common Success Factors. Bangkok: Ewha Women's University.

Sirma, J., Obegi, F., \& Ngacho, C. (2014). An Analysis of Factors Influencing Implementation of Computer Based Information Systems in Public Universities in Kenya: A Case Study of Egerton University. Information and Knowledge Management, 4(8).

Vaughan, P. J. (2003). System Implementation Success Factors: It's not just the Technology. Boulder, Colorado: University of Colorado.

Ziemba, E., \& Oblak, I. (2013). Critical Success Factors for ERP Systems Implementation in Public Administration. Interdisciplinary of Information, Knowledge, and Management, 8(1). 